"Clothing in the Early Ghaznavids Courts: Hierarchy and Mystification ». St. Ir., 32 (2003), pp. 213-242.

David Durand-Guédy

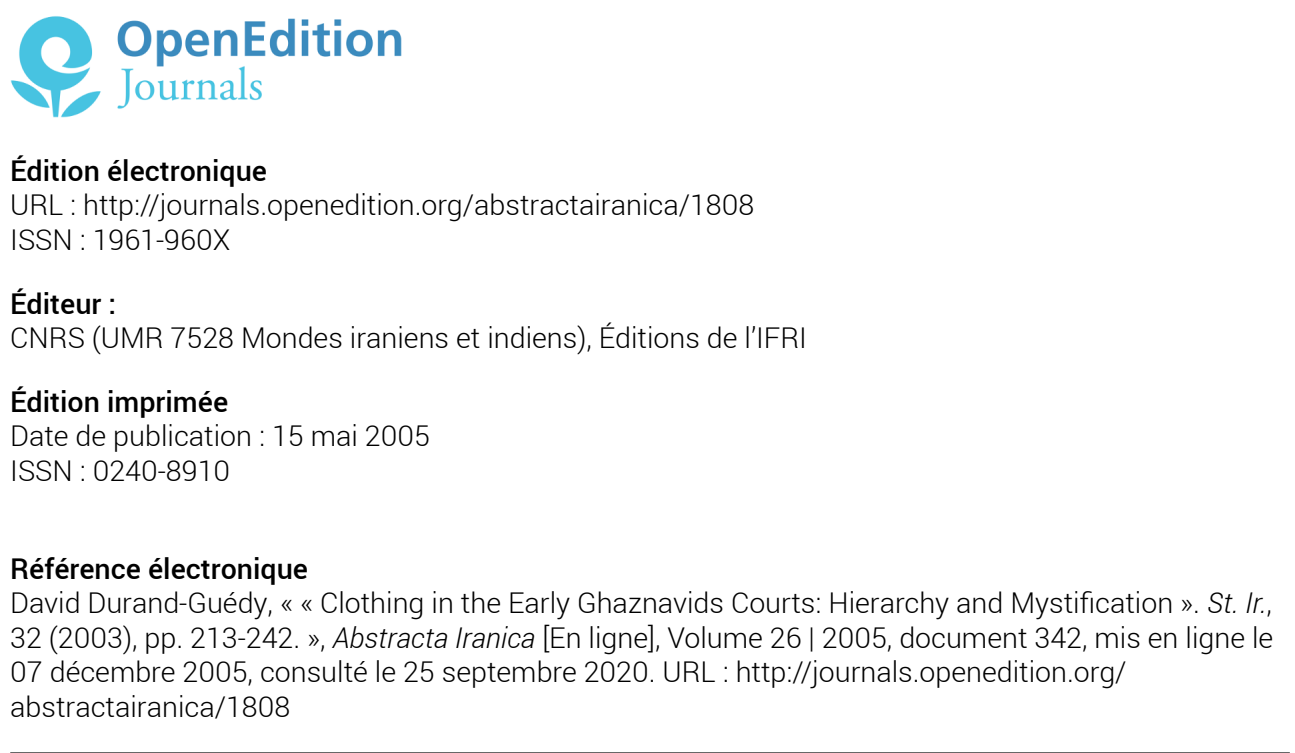

Ce document a été généré automatiquement le 25 septembre 2020.

Tous droits réservés 


\title{
"Clothing in the Early Ghaznavids Courts: Hierarchy and Mystification ». St. Ir., 32 (2003), pp. 213-242.
}

\author{
David Durand-Guédy
}

L'A. commence par un exposé général sur ce que l'on sait des pratiques vestimentaires dans l'Orient musulman (travaux de Dozy, Sergeant, Stillman). Ensuite, elle analyse la manière dont le vêtement apparaît dans les sources composées à la cour des premiers sultans ġaznavides (divans de (Unșūrī, Manūčihrī et FarruH̄īi TārīH-e Bayhaqī), en détaillant par exemple les verbes associés aux vêtements ou encore les expressions vestimentaires décrivant des émotions. Dans la dernière partie, elle expose sept histoires, presque toutes tirées de l'histoire de Bayhaqī, qui permettent de montrer en quoi les vêtements reflètent le statut social des courtisans, ou l'idée qu'ils veulent donner d'eux-mêmes. Ce travail, très descriptif, relève plus de la critique littéraire que de l'analyse historique.

\section{INDEX}

Thèmes : 11.1.1. Littérature persane classique

nompropre Ġaznavides, (Unșūrī, Manūčihrī et FarruHīi, Bayhaqī 
AUTEURS

DAVID DURAND-GUÉDY

IFRI - Téhéran 